\title{
Criminology Study on Pedophilia Prevention in Inonesia
}

\author{
Tri Akhmad Aji Saputra \\ Faculty of Law of Universitas Diponegoro \\ aji.jibul90@gmail.com \\ Eko Soponyono \\ Faculty of Law of Universitas Diponegoro \\ ekosoponyono@gmail.com
}

\begin{abstract}
Children are frequently victims of misconduct regarding the current widespread sexual abuse perpetrated by elders who are usually known by them, it is called pedophiles. Criminology reviews, therefore, are very crucial to analyze the crime. Pedophilia is a psychiatric disorder in which an adult experiences a primary or exclusive sexual attraction to pre-pubescent children, the cut-off point for pre-pubertal to age 13. The disorder results in sexual abuse, including Nepiophilia or Infantophilia that is sexual attraction to infants under 3 years old. Pedophiles, then, are adults of deviant sexual behavior abusing children. This study is aimed to examine and analyze criminology reviews for prevention of pedophile crime. It is normative juridical approach (statute approach), the conceptual and the comparative one. The factors of committing pedophilia are internal of the personal perpetrator, and external in which the community vastly influences on committing the crime and to shape how someone becomes a bad person or good one. Thus, to overcome the crime is to carry out preemptive, preventive, repressive and rehabilitative methods. In addition, one of child protection policies to anticipate child sexual abuse increase including pedophiles, the Government issued a regulation (Perpu) No. 1 of 2016 on the second amendment of Act No. 23 of 2002 of the children protection. The Government Regulation (Perpu) No. 1 then is legislated as Act 17 of 2016. Based on comparative studies of other countries, there is a voluntarily castration in which the perpetrators must be ready to be emasculated, aimed to reduce or suppress their libido. Yet, Indonesia values emphasizing Pancasila (Five Principles) must be referred: just and civilized humanity (humanism).
\end{abstract}

Keywords: Criminology; Crime; Pedophile

\section{A. INTRODUCTION}

One of National Development programs is children protection regarding thoroughly protection and development of humankind. Due to lack of children protection, social problems arise and disturb order, security and national development (Gosita, 1985). Children protection is to assure children rights and obligations on behalf of manifestation of justice somewhere in society, so that children protection is performed in all sectors of state and society. 
Children are the one and only God's grace in which their rank and dignity must be protect, their rights must be assured to grow up their childhood. To be generation of nation, children must achieve their rights and needs sufficiently, and anyone must not treat them indiscriminately and inhumanly due to they are susceptible to violence and misconduct. They, therefore, must be taken care and educated as good as possible in order to grow up genuinely.

Children are an inseparable part of sustaining human life, nation and state. Regarding such important rule of them, children's rights are recorded in Article $28 \mathrm{~B}$ Paragraph 2 of 1945's Constitution in which "Every child shall have the right to live, to grow and to develop, and shall have the right to protection from violence and discrimination." We, therefore, attempt to prevent children from any violence and criminal deeds or other wrongdoings.

Sexual abuse is usually regarded as a mere bad morality, and moreover the point of view is affirmed by State based on the Criminal Law (KUHP). In this code of law, sexual abuse like rape is regarded as violation of ethics in such a way that this category does not only reduce the criminal case, but also results in opinion that sexual abuse is just only ethical issue (Mardiya, 2017).

Children are frequently victims of misconduct regarding the current widespread sexual abuse perpetrated by elders who are usually known by the victims themselves, it is called pedophiles. Criminal action of pedophilia takes place in children community such as family, school, and playground as well as the perpetrator could be from children's neighbors, families and close people. In this case, little boys and girls both could be the victims of the crime.

The child victims of sexual abuse in the last couple years' increase. In 2002, $33 \%$ of sexual abuse is child victims from six to twelve years old, and around $28.8 \%$ is child victims of mental violation, in comparison with $24.1 \%$ of physical assaults (Huraerah, 2006). In 2017, Indonesia's Child Protection Commission (KPAI) discovered 116 cases of child sexual assault. Jassa Putra, the commissioner of KPAI, disclosed data that he found out 218 cases of child sexual assault in 2015, meanwhile in 2016, KPAI recorded 120 case and in 2017, 116 cases (Krismiyarsi, 2018).

Based on the data, we come to conclusion that the rate of child violence and sexual abuse is still high. The children as encouraging generation of this nation must be victims of inconceivable adults' violence. Child protection, therefore, is natural and realistic, aside from children's rights and responsibility of all sides of Indonesia.

It is noteworthy that the little boys of sexual abuse victim who is repelled and disregarded by their family, could be pedophilia perpetrator in their teenage years and adulthood of the very fact that porn videos as the cause of sodomy could be the 
secondary one, that is, the perpetrator actually is the victim in childhood, and unable to control lust aroused by the porn videos.

Based on the description, pedophilia is not genetic heredity, but it is learned through others in social intercourse. It is in line with what Edwin Sutherland premise pertaining to differential association theory (Abdussalam, 2007). This research, therefore, is aimed to study furthermore about pedophilia and its prevention through criminology outlook.

\section{B. RESEARCH METHOD}

Legal study is scientific pathway based on certain methods, systematics and theories, aiming to study one or more legal phenomenon, through analysis (Soekanto, 2006). Considering research's problems and its objective, the study's approach is legal-yuridical-normative one through literature or secondary data (Soekanto \& Mamudji, 1985).

The approaches consist of normative juridical (statute), the conceptual and the comparative ones. The study, therefore, finds out and collects the necessary data, revolving around main cases to avoid deviation and ambiguity of discussion. This research employed secondary data including primary and secondary and tertiary legal ones.

\section{DISCUSSION AND ANALYSIS}

\section{Criminological reviews of Pedophilia}

The term criminology was coined in 1885 by Italian law professor Raffaele Garofalo as criminologia. Later, French anthropologist Paul Topinard used the analogous French term criminologie. Criminology (from Latin crimen, and Ancient Greek logia), is the study of the nature, extent, management, causes, control, consequences, and prevention of criminal behavior, both on individual and social levels (Utari, 2012).

The etymology of criminology refers to crimen, crime, and logos which means knowledge or science. According to Sutherland, criminology is a set of knowledge studying crime as social phenomenon including law-making, violation of law, and social reaction to the violation (Susanto, 2011). In this case, criminology is not only a science studying crimes, but also law-making, violation of law, and social reaction to the violation and policy making of government in manifold.

And according to Goerge Vold, there is a twofold problem in studying criminology, which means, human conduct and social conventions and perceptions on what is allowable and forbidden, good and evil, contained in laws, social habit and customary law; and according to Durkheim, the sociology expert, crime is normal due to there is no society without crime (Abdussalam, 2007). 
Crime is somehow indispensable, due to the dynamical society is based on behavior mobilizing it and initially it is called crime. It, therefore, is not natural phenomenon, but social and historical ones, as it must be recognized, categorized and realized as crime and the society certainly has norms, rules and laws to be violated so that there are also institutions serving as law enforcement and to sentence to its offenders. According to Paul Moedigdo, the criminals shares offences due to their motives to commit crime resisted by society (Abdussalam, 2007).

The extent of criminology covers three-fold studies (Alam, 2010):

a. Law making contains in:
1) Crime definition
2) Crime factors
3) Relative definition of crime
4) Crime classification

b. Crime figures Etiology of crime is to reveal theories of crime causation (breaking the law), pertaining to:

1) Criminology schools

2) Theories of criminology

3) Perspectives of criminology

c. Reaction toward the breaking of laws, not only referring to criminals, but also reaction of would-be criminals in terms of criminal prevention, consist of:

1) Theories of punishments

2) Prevention of breaking the law through pre-emptive, preventive, repressive and rehabilitative methods.

Criminology reviews is needed to study crime, especially pedophilia as child sexual abuse under 13 years old or younger, including nepiophilia or infantophilia, that is, sexual attraction to infants under 3 years old. Pedophilia is mental deviation of adult experiencing sexual attraction to pre-pubertal children. There are some theories in criminology to be employed in finding out the causes of crime or criminal act, especially pedophilia crime. In this case, psychogenesis and differential association theories could be employed. Psychogenesis is theory in which focus on the causes of human misbehavior viewed from psychological aspect or psychiatric one, namely human's personality, intellegency, fantasy, emotional conflict, and motivation (Putri, 2018). While differential association is a theory developed by Edwin Sutherland proposing that through interaction with others, individuals learn the values, attitudes, techniques, and motives for criminal behavior. Thus, pedophilia does not originate in heritable or genetic factors, but adult's behavior learnt through interaction in such a way that all sides of society, especially criminology expert and upholder of the law, must pay thoughtful attention to the crime (Abdussalam, 2007). 
Some studies find out that a number of pedophiles (especially their attraction of male minors apart of their family and relative) have emotional harmony with children other than sexual offenders. The harmony is in what extent to sexual intercourse could comply with emotional needs. Emotional harmony comprises how the perpetrators of pedophilia to select some minors accompanying them, running activities with children and thinking that emotional and intimate needs could be met by children. Some pedophiles do not only drive at sexual intercourse with children, but look for romantic moment with them, and other to think that their intercourse with children is just only platonic (Andina, 2017).

According to psychology, a pedophile is regarded as one of individual disorders consisting of (Akhdiat \& Marliani, 2011):

a. Drug addiction, is a kind of deviation of norm, moral and religion

b. Prostitution, due to personal immature life or imbalance of personality

c. Sexual deviation, that is, abnormal sexual intercourse. Some sexual deviations are lesbians and homosexuality, sodomy, transvestism, sadism, pedophilia, adultery, free sex.

In pedophilia, there is relationship of the personal past of pedophile with sexual life and psychological development in childhood. The research likewise pointed out that little boy suffering sexual abuse, tends to be pedophile, meanwhile little girl as victim of pedophilia, tends to be self-destruction like to be drug addiction and prostitute.

Criminal factors of pedophilia are internal ones just like genetic heredity, and external ones just like environmental influences. The both factors determine pedophilia. Another factor is economical ones. Based on differential association theory, developed by Sutherland, social interaction is a factor lead to crime. The theory is based on learning, that is, the individuals learn to become criminal, so that based on it, pedophilia is a crime learnt through pedophilia in social relationship. The pedophilia likewise could be learnt through pedophile due to be former victim of the crime itself and the process of learning could consist of a certain motive, biological imperative and justification. In this case, genetic heredity is apart from the criminal factor of pedophilia, it is not the generated by genetic factor (Abdussalam, 2007).

For Bonger, in addition to internal factors as personal one, external factor, among other community, has a great effect to crime. The influences determine whether someone will be evil or good (Soejono, 1976). On the other side, low economic level and unemployment could trigger pedophilia, according to Aristotle's view pointed out that poverty leads to rebellion and crime. Such a crime is carried out to get basic needs, but actually, more boosted by greed for superfluous wealth and pleasure (Kartono, 1981). 


\section{To Overcome Pedophilia}

One can compare plainly that to overcome the crime is to put into practice the penal as repressive method of post factum crime, and non-penal method is applied as preventive measure prior to the crime happens, but repression likewise implied prevention in broader meaning (Sudarto, 1983).

For Barda Arief, policy to overcome the crime substantially is integral part of social defense and realization of social welfare. It, therefore, could be said that the end or main objective of policy toward crime, is social security to achieve prosperity (Arief, 2016).

Clear resolution of significance overcoming the crime (pedophilia) is integrated with all social policies and national development plan, addressed as follows (Arief, 2016):

a. Sudarto have already stated that as Personal Criminal Code (KUHP) must be integrated with overcoming negative sides of modernity (crime prevention), it must be reviewed in relation with whole political method to overcome the crime or social defense as well as the integral part of national development program.

b. Clifford once put forward in "The 32nd International Seminar Course on Reform in Criminal Justice", 1973, Japan, that:

"... on the one hand there is the need for a wider view of criminal policy as an integral part of general political and social policy of given country. It is a reflection of local mores and customs and a byproduct of development. From this wider viewpoint criminal policy cannot be something apart from the more general social situation but must be developed from it and through it".

Considering these descriptions, coping with overcoming crime (especially pedophilia) to protect society, I eventually come to put forward three steps as follows:

First, pre-emptive measure is preliminary action of police department to avoid crime through instilling righteous values or norms in order to internalize them. Even though there is a chance to break the law, the crime could not happen due to there is no will to commit it. Thanks to the pre-emptive measure, the will is gone. In this case, police department carries out spiritual and mental guidance and collaborates with society figures and religious leaders to increase awareness of significance to realize religious values in social life, in order to minimize the crime including pedophilia. Yet, such a pre-emptive measure should be in line with other effort. Bonger (1981) likewise thought that the most important prevention to avoid crimes is morality so that we must expand the means to reinforce morality in order to avoid evil passion. 
Second, preventive measure as further action of pre-emptive one which is still to avoid before actual pedophilia. The preventive measure emphasizes exclusion of chance to commit the crime. The stakeholders to be responsible for it are individuals, community, civil servants and polices.

Third, repressive measure is employed in term of the crime for law enforcement, by punishment. The measure must be run according to regulation and police law. The officer is prohibited to violate the procedures, and in case the officer commits the violation, it must be punished as well. In addition of police department, the judiciary institution and judges have important role to overcome the crime. Regarding pedophilia, the attorney serves as an agent of investigation for case file after police investigation and filed a claim in front of the court. The judges, then, decide punishment for the sake of law enforcement and provide deterrent effect for the pedophiles to rehabilitate their attitudes mental deviation and decline to commit their crime anymore.

In addition to overcome pedophilia by penal and non-penal methods, it is also possible to apply the idea of Crime Prevention through Environmental Design. Such an approach is alternative one to reduce or prevent crimes through designing towns or environments to straighten or reduce chance for committing the crimes. One of unwittingly environmental design is to let in as many individuals as possible for monitoring and preventing the strangers coming in the community, by idea of "easily visible and supervised", open monitoring and limit free access to the community (Aquina, 2015). Alongside this alternative approach, The Center of Integrated Services for Empowering Women and Children could also maximalize its role to prevent pedophilia crime as it regulated by Minister Regulation of Women Empowerment and Child Protection No. 2 Year 2010 on National Action Plan for Children Abuse Prevention (Article No 4-8); to advocate, socialize and educational information communication (Romantika, 2014).

By means of legal remedies including criminal law for overcoming social problems, is policy of law enforcement. Due to the aim is to attain social welfare, law enforcement social policy is part of social policy as a rational effort. For it is a policy, legal remedy is not a must (Muladi \& Arief, 1998). To accommodate social need and aspiration, Indonesia made social policy as program to realize social welfare and social defense policy (Arief, 2001).

For Erna Dewi (2013), penal determination for one part is general prevention and on the other part to special one. General prevention is aimed to influence other potential perpetrator and all part of society to obey the law. Special prevention is direct effect of penal determination for the criminal in order to be a good people later. In other word, by penal determination, it is expected to end recurrent crime committed by the same criminal. 
One of child protection policy to anticipate the increase of child sexual abuse including pedophilia, Indonesia government issued a regulation (Perpu) No. 1 of 2016, on the second amendment of Act No. 23 of 2002 of the children protection. The Government Regulation (Perpu) No. 1 then is legislated as Act No. 17 of 2016. The regulation is about deepening punishment for sexual crime, especially child sexual abuse. It includes penal and legal action in which the criminals should be punished by chemical castration and rehabilitation.

The government saw that child sexual violation achieve extraordinary rate and boost to take extraordinary action to overcome the crime. It, therefore, issued a new regulation to make deterrent effect just like the aforementioned Government Regulation No. 1 of 2016 and its amendment to be Act No. 23 of 2002.

Chemical castration is a mean to inject anti-testosterone substance to the body in order to decrease testosterone hormone which has various functions, such as sexual impulse, as the chief person of Andrology and sexology faculty, Udayana University, Denpasar, Wimpie Pangkahila said. For the chief person, the process to decrease testosterone hormone, is through pill or injection of anti-androgen. In this case, injection of anti-androgen results in the same effect as physical castration (Hasanah \& Soponyono, 2018).

The extra penalty of chemical castration can be executed for the relapse perpetrator and for resulting in much more victims, hard injured victim, mental disorder, infectious diseases, reproduction damages and death, except for child perpetrator. Yet, the regulation has some problems among other pertaining to procedure of extra penalty just like installation of electronically monitoring device and supervision toward the criminal and castration, were regarded that all techniques are incompatible in Indonesia due to they need much more resources such as budgets, human resources, means and other infrastructures. Regarding installation of detection device, police department proposed the review due to Indonesia has denser population and least infrastructure.

In terms of chemical castration, the punishment relating to the Regulation, for a number of researches, the usefulness of castration for reduction sexual crime is problematical due to its lack of scientific evidences, so that the regulation is irrelevant to follow up and every policy making of overcoming sexual crime in Indonesia, must be based on scientific reason, valid data and evidence, in favor of emotional impulse to resist the crime. As the formulation of regulation was carried out in short duration, it is lack of comprehensive studies and researches in regard of effectiveness and long term effect of the regulation. Consequently, the regulation is regarded as reactionary measure, as various punishments in the regulation are reactionary and bombastic, not based on comprehensive considerations to formulate long term punishments (Andari \& Kajian, 2017). 
On the other hand, the chemical castration execution is refused in which it involves Indonesia Physicians Association (IDI) as the main executor, because in terms of health care, the execution rather results in many negative effects (Firmanto, 2017). This refusing came from the thought that the castration executed by doctor is contradicting with Indonesian medical ethics (Malian, 2016). The chemical castration process could paralyze parts of body so that it could be a kind of torture. It does not result in perpetrators to be better, but get rid of their self-confidence and results in ill tempered. The medical experts likewise refuse the execution due to it results in more aggressive personality of the perpetrator, and do not assure recurrent crime of the same criminals due to their sexual memory remains in the mind, although testosterone hormone have decreased, so that it results in a new kind of crime. Thus, punishment based on regulation and law, must consider whole rehabilitation in terms of medical, psychological and social point of view and human rights.

Based on policy and effectiveness of the regulation evaluations, the policy would not assure yet strong legal security to overcome child sexual abuse in Indonesia. World Rape Statistics of 2012 reported that castration penalty for the pedophiles around the world, is ineffective and no deterrent effect. There is no evidence that the chemical use for castration can reduce violation rate against women and children (Mardiya, 2017). Every country performing death penalty and castration execution, exactly rank in top ten of crime rates.

\section{CONCLUSION}

The research comes to conclusion that pedophilia comprise some factors, internal one pertaining to the personal perpetrator, and external in which the community vastly influences on committing the crime and shape how someone becomes a bad person or good one. Based on criminology reviews of pedophilia, method of analysis is differential association theory and criminal psychology. According to differential association theory, through interaction with others, individuals learn the values, attitudes, techniques, and motives for criminal behavior. The criminal psychology emphasizes deviation of personal behavior pertaining to personality, intelligence, obsession, internal self-conflict, emotional and motives.

To overcome the crime is to carry out pre-emptive, preventive, repressive and rehabilitative methods. Accordingly, one of child protection policies in Indonesia to anticipate child sexual abuse, including pedophiles, is increasing. the Government issued a regulation (Perpu) No. 1 of 2016 on the second amendment of Act No. 23 of 2002 of the children protection. The Government Regulation (Perpu) No. 1 then is legislated as Act 17 of 2016. 


\section{REFERENCES}

Abdussalam. (2007). Kriminologi. Jakarta: Restu Agung.

Akhdiat, H., \& Marliani, R. (2011). Psikologi Hukum. Bandung: Pustaka Setia.

Alam, A. S. (2010). Pengantar Kriminologi. Makasar: Pustaka Refleksi.

Andari, R. N., \& Kajian, P. (2017). Evaluasi Kebijakan Penanganan Kejahatan Kekerasan Sesksual Terhadap Anak di Indonesia (Evaluation Policy of Carrying Out of Sexual Violence Crimes of Children). Jurnal Ilmiah Kebijakan Hukum, 11(1), 1-11.

Andina, E. (2017, March). Pedofil Online dan Perlindungan Anak. Majalah Info Singkat Kesejahteraan Sosial, IX(06), 1-4. Retrieved from http://berkas.dpr.go.id/puslit/files/info_singkat/Info Singkat-IX-6-II-P3DIMaret-2017-232.pdf

Aquina, D. (2015). Belajar Perlindungan Anak dari Predator Seksual di New York | Money.id. Retrieved May 5, 2018, from https://www.money.id/news/belajarperlindungan-anak-dari-predator-seksual-di-new-york-1510107.html

Arief, B. N. (2001). Masalah Penegakan Hukum dan Kebijaka Penanggulangan Kejahatan. Bandung: PT. Citra Aditya Bakti.

Arief, B. N. (2016). Bunga Rampai Kebijakan Hukum Pidana. Semarang: Prenamedia.

Bonger. (1981). Pengantar Tentang Kriminologi. Jakarta: PT. Pembangunan Ghalia Indonesia.

Dewi, E. (2013). Sistem Minimum Khusus dalam Hukum Pidana Sebagai Salah Satu Usaha Pembaharuan Hukum Pidana Indonesia. Semarang: Pustaka Magister.

Firmanto, A. A. (2017). Kedudukan Pidana Kebiri Dalam Sistem Pemidanaan di Indonesia (Pasca Dikeluarkannya PERPPU No. 1 Tahun 2016). Jurnal Hukum Novelty, 8(1), 1-19.

Gosita, A. (1985). Masalah Perlindungan Anak. Jakarta: Akademika Pressindo.

Hasanah, N. H., \& Soponyono, E. (2018). Kebijakan Hukum Pidana Sanksi Kebiri Kimia dalam Perspektif HAM dan Hukum Pidana Indonesia. Jurnal Magister Hukum Udayana, 7(3), 305-317.

Huraerah, A. (2006). Child Abuse (Kekerasan Terhadap Anak). Bandung: Nuansa.

Kartono, K. (1981). Patologi Sosial. Jakarta: Raja Grafindo Persada.

Krismiyarsi. (2018). Kebijakan Sanksi Kebiri Kimia Bagi Pelaku Kekerasan Seksual Terhadap Anak Kajian Politik Hukum Pidana. Seminar Nasional Hukum Universitas Negeri Semarang, 4(1), 92.

Malian, S. (2016). Analisis Kenuikan dan "Missing Link" Antara Hukum Pidana Internasional, Etika Profesi, dan Politik; Telaah Kritis PERPPU Nomor 1 Tahun 2016 Tentang Perubahan Atas UU Nomor 23 Tahun 2002 Tentang Perlindungan Anak. Jurnal Hukum Novelty, 7(2), 168-181.

Mardiya, N. Q. (2017). Penerapan Hukuman Kebiri Kimia Bagi Pelaku Kekerasan Seksual Implementation of Chemical Castration. Jurnal Konstitusi, 14(1), 18. Retrieved from https://media.neliti.com/media/publications/114882-IDpenerapan-hukuman-kebiri-kimia-bagi-pela.pdf

Muladi, \& Arief, B. N. (1998). Teori-Teori dan Kebijakan Pidana. Bandung: Alumni.

Putri, P. D. (2018). Tinjauan Kriminologis Tindak Pidana Pencabulan Anak Di Bawah Umur (Studi Kasus Di Kota Surakarta). Universitas Muhammadiyah Surakarta.

Romantika, P. (2014). Upaya Pencegahan Kekerasan Seksual Terhadap Anak Oleh Pusat Pelayanan Terpadu Pemberdayaan Perempuan dan Anak (P2TP2A) di Kabupaten Wonogiri. Universitas Islam Negeri Sunan Kalijaga.

Soejono, D. (1976). Penanggulangan Kejahatan (Crime Prevention). Bandung: 
Alumni.

Soekanto, S. (2006). Pengantar Penelitian Hukum. Jakarta: UII Press.

Soekanto, S., \& Mamudji, S. (1985). Penelitian Hukum Normatif: Suatu Tinjauan Singkat. Jakarta: Rajawali.

Sudarto. (1983). Hukum dan Hukum Pidana. Bandung: Alumni.

Susanto, I. S. (2011). Kriminologi. Yogyakarta: Genta Publishing.

Utari, I. S. (2012). Aliran dan Teori dalam Kriminologi. Yogyakarta: Thafa Media. 